Vol. 4, No. 1, January 2016

Jurnal llmial

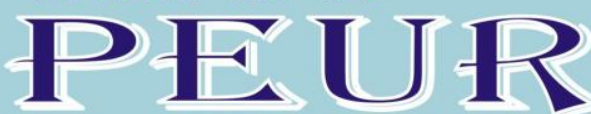

Media Kajian Ilmiah Sosial, Politik, Hukum, Agama dan Budaya
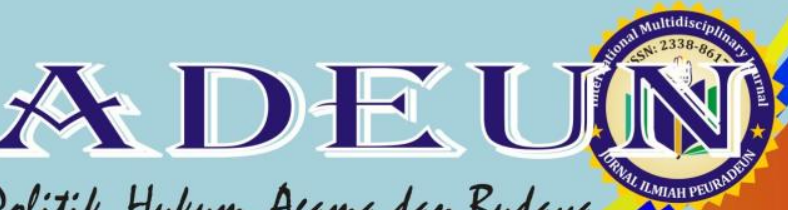


\title{
THE CURRENT CIRCUMSTANCES AND CHALLENGES OF MIGRANT LABOR FORCE OF MONGOLIA IN NORTH EASTERN ASIA
}

\author{
1Z.Altanchimeg, ${ }^{2}$ D.Battuya, ${ }^{3}$ J.Tungalag \\ ${ }^{1}$ Department of Management, Business School, National University of Mongolia \\ ${ }^{2}$ Accounting, Business School, National University of Mongolia \\ ${ }^{3}$ Department of International Trade, Business School, National University of Mongolia \\ E-mail: altanchimeg_zana@yahoo.com
}

Received: Aug 21, 2015

Accepted: Dec 29, 2015

Published: Jan 21, 2016

Article Url: https://journal.scadindependent.org/index.php/jipeuradeun/article/view/83

\begin{abstract}
The current study addressed the current circumstances and challenging issues for the Mongolian migrants. We involved in the survey citizens who have been lived and worked in the Republic of South Korea and Japan. According to the results of the survey, working of Mongolian citizens in hazardous and insecure working conditions reveals the weak coherence between regulation and policies towards to the immigration and professional organizations. We concluded that one of the priorities in the area should be developing a sound policy on migrant labor force that meets international labor standard with considering of economic, social policies and then in the implementation process establishing centralized database is crucial.
\end{abstract}

Keywords: Labor Market, Work Force, Migration 


\section{A. Introduction}

One of the key factors in the development of any country is efficient use and development of the labor force. Especially, the migration of labor force contributes to meeting labor market demand, increasing the number of skilled, educated and high value population in a country as well as impacts favorably to the growth of economy and the development. It is beneficial both for sending countries and receiving countries. Thus, maintaining a sound and viable policy on migrant work force will enable protecting migrant working force and manage it efficiently.

Researchers have noted social and economic negative impacts resulted due to the immigration of the labor force from our country (Jandos. S, 2014). Moreover, there is a need for learning international experiences and policies and researching labor force and migration as the number of expatriates working in Mongolia has been increasing recently.

Objectives of the study: "The present circumstances and challenges of Mongolian migrant work force in the Republic of Korea and Japan" aimed at studying the reasons for immigration of Mongolian citizens to North East Asia and its' impact, challenges for Mongolian citizens and evaluating policies and programs implemented by the government.

\section{B. Theoretical Part}

Migration or immigration is a process when people move from their permanently living places to another geographical units or administration. Migration or immigration takes a place within a country and from a country of origin to the selected country. Labor force migration is one of the common practices of economic migration.

Although there is a diverse models explaining the immigration one theory of immigration distinguishes between push and pull factors. The theory focuses socio-economy policies and social relations. From this perspective the economic prosperity of a country can be rated by on how human rights of migrant work force reflected in the regulations and policies of the country. In one word according to Castles and Miller (2003: 21) migration or immigration is a detailed system of international immigration, 
implementation practice and factors influencing to it and their inter-relations. Economical and historical or structural approaches are considered in immigration. Migration is considered as a system with macro and micro structures that are related both for private and public sectors and individuals. In other words it can be explained by interactions of countries and their internal policies. The best practices of implementing above approaches in South East Asia are Indonesia, Malaysia, and Singapore that could successfully implement economic policy based on the historical relations (Miller's The Age of Migration 2003).

When evaluate the economic contribution of the migration in social context human resource, labor and social issues, and their optimal ration and international cooperation are considered.

In the social context the human resource and proper labor issues are involved and specially, migration of labor force is getting an important issue in numerous countries in the world. In one side labor force whose home countries have a limited employment opportunity in the labor market, in another side host countries have deficiency of labor force in various sectors of economy and the first ones are possible to filling the existing gap of the second one.

Despite the main variances also number of factors such as democracy in developing and well developed countries, social \& economic issues, crisis in politics and huge difference in value of wages.

The most concerned issues in migration were gender and working condition issues. In solution of these issues not only governments of countries but also international cooperation is essential. In migrant labor force the approach that based on the ensuring the rights is used frequently to facilitate satisfying the labor market demand of host country for improving the mutual understanding.

This approach is implemented based on recommendations of the countries with migration work force to create economically sound international labor force migration, international labor standard and best practices. The decisions made within this area concerning implementation, development and possibilities for enhancement are reflected in the manual and provided to the employers, organizations representing employees and governments. 


\section{The current circumstances and challenges of migrant labor force of Mongolia in the Republic of Korea and Japan}

Migration of labor force has started by initiatives of the private company since 1998 and upon approval of the Law on delivering labor force and receiving foreign labor force from overseas since 2001 the activity has legally recognized.

The current activity is conducted by the government quota system and bilateral governmental agreement. Migrant labor force has been delivered to the Republic of Korea, Japan and Czech Republic. For delivering the labor force the Memorandum of Understanding signed by the ministries of two countries and for delivering internees the contract signed by professional authorities and ministries are the main legal documents regulating the process. Despite the above mentioned law number legal acts and documents including the Constitution, Labor Law, Law on status of foreign citizens and law on social welfare insurance.

By 2014, 132791 Mongolian citizens lived and worked in overseas countries. Fourteen thousand of them are working by contract and production internees and 33 thousand of them lived illegally.

The activity in the Republic of Korea is regulated by the Memorandum of Understanding signed by the Ministers of Labor of two countries. The number of migrant workers fluctuates slightly depending on the economic and social conditions. By the 2013, out of 24705 Mongolian citizens $68.5 \%$ were living and working legally and remaining 7774 were illegal migrants.

Table: 1 Status of Mongolian citizens living and working in Korea

\begin{tabular}{l|c|c|c|c|c}
\hline \multicolumn{1}{c|}{ Criteria } & $\mathbf{2 0 0 9}$ & $\mathbf{2 0 1 0}$ & $\mathbf{2 0 1 1}$ & $\mathbf{2 0 1 2}$ & $\mathbf{2 0 1 3}$ \\
\hline $\begin{array}{l}\text { Number people in } \\
\text { this country }\end{array}$ & 30976 & 29920 & 29843 & 28720 & 24705 \\
\hline - Legally & 18705 & 19037 & 20175 & 20040 & 16958 \\
\hline - Illegally & 12270 & 10883 & 9668 & 8680 & 7747 \\
\hline $\begin{array}{l}\text { Workers with the } \\
\text { contract }\end{array}$ & 11867 & 10978 & 10678 & 10222 & 9879 \\
\hline
\end{tabular}

Source : www.moj.go.kr( Ministry of Justice, Korea )

There have been observed the decrease of the number of illegal migrants and contracted workers in the Republic of Korea in recent years. 
It is related to the decrease of the vacancy offers from Korean side and consequently the quota number decreased.

In 1998 former Ministry of Health and Social Welfare and Japan International Training Cooperation organization concluded the contract on sending professionals for internship program. The current activity is implemented via brokerage organizations with special permissions and the number of internees remains steady year by year. ${ }^{1}$

Figure 1: The number of immigrant workers sent to the Republic of Korea and Japan

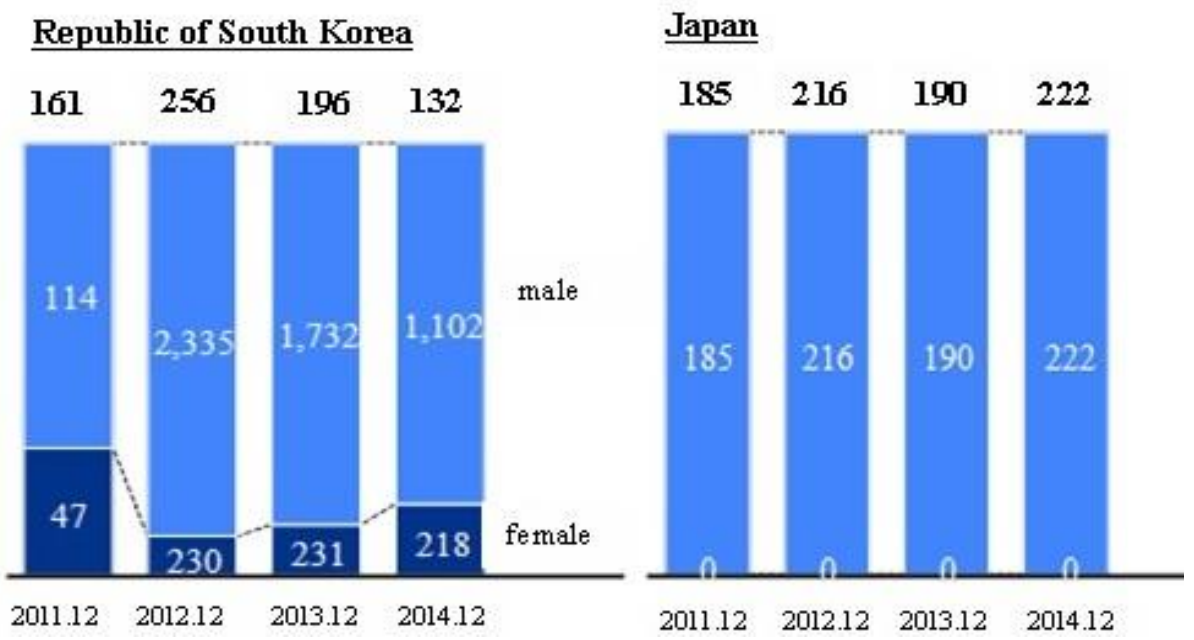

Source: Ministry of Labor, the National Employment, Research and Information Center report

The migration remains active in Mongolia due to the political and social conditions that lead to the unstable income of the population and limited job opportunities. However, Mongolian citizens suffer from working in hazardous conditions, inability to receiving the pay, get victims of production accidents, loss of health and life and face racial discriminations and suffer from violation of their human rights. ${ }^{2}$

There have been observed a sharp increase of the migration due to population income decrease as the economic situation of the remains weak in

1 Ministry of Labor, Human right's education program, labor force immigration department report 2014

2 "Implementation of some rights of Mongolian citizens working in the Republic of Korea” research report, Ministry of Labor, 2007 
the past a few years. Although unsolved challenging issues remain in the migration, new issues are coming related with the phenomena. Therefore, there is a demand for obtaining data on migrant labor force of Mongolia working in foreign countries and evaluate their contributions to the economy and society and study the challenges they face.

We involved 222 citizens living in the Republic of Korea and 25 citizens working in Japan.

Table 2: Background information on respondents (age, education, sex, marriage status)

\begin{tabular}{|c|c|c|c|c|c|c|c|c|c|}
\hline \multicolumn{2}{|c|}{$\begin{array}{c}\text { Residential } \\
\text { status }\end{array}$} & \multicolumn{2}{|c|}{ Age } & \multicolumn{2}{|c|}{ Sex } & \multicolumn{2}{|c|}{$\begin{array}{c}\text { Education } \\
\text { background }\end{array}$} & \multicolumn{2}{|c|}{ Marriage status } \\
\hline Status & $\%$ & Age & $\%$ & Sex & $\%$ & Level & $\%$ & $\begin{array}{c}\text { If } \\
\text { married } \\
\text { or not }\end{array}$ & $\%$ \\
\hline $\begin{array}{l}\text { Worker } \\
\text { with a } \\
\text { contract }\end{array}$ & 51 & $18-25$ & 28.7 & \multirow{2}{*}{$\frac{0}{\sum^{\pi}}$} & \multirow[t]{2}{*}{70.9} & $\begin{array}{l}\text { Higher } \\
\text { education }\end{array}$ & 47 & \multirow{2}{*}{ 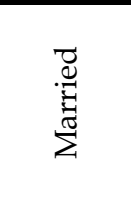 } & \multirow[t]{2}{*}{68.4} \\
\hline $\begin{array}{l}\text { Illegal } \\
\text { workers }\end{array}$ & 21.9 & $26-35$ & 42.5 & & & $\begin{array}{l}\text { Professiona } \\
1 \text { education }\end{array}$ & 13.8 & & \\
\hline Student & 16.6 & $36-45$ & 18.6 & \multirow{3}{*}{ 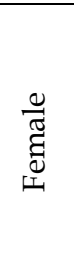 } & \multirow{3}{*}{29.1} & $\begin{array}{l}\text { Complete } \\
\text { secondary } \\
\text { education }\end{array}$ & 25.5 & \multirow{3}{*}{ 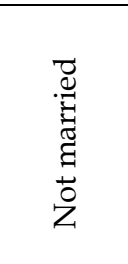 } & \multirow{3}{*}{31.6} \\
\hline $\begin{array}{l}\text { Permanent } \\
\text { resident }\end{array}$ & 5.7 & $\begin{array}{l}45 \\
\text { and }\end{array}$ & 101 & & & Incomplete & 137 & & \\
\hline Other & 4.8 & above & & & & education & & & \\
\hline
\end{tabular}

By residential status $51 \%$ of the respondents of the survey were workers with contracts, and $21.9 \%$ of them were illegal workers, and $16.6 \%$ of the respondents were students and $5.7 \%$ were permanent residents. Seventy one point two percent of the respondents were people at age of 18-35 years old.

Majority of the respondents or $70.9 \%$ are male. It shows that mostly the employment offers from Korea are mainly for male population. According to the background information of the $68.4 \%$ of the survey participants were married and $64.8 \%$ of them replied that they have children which likely lead to having family and social issues.

The development of the strategy on gender and human development is completed and in process of approval. It created the possibility of paying 
the pension insurance fee for the migrant workers in Korea. Moreover, marriage with the citizen of host country and citizenship issue of the children born in these families is getting concerning issue these days, as the legal regulation is missing.

In 2015, 10980 couples claimed to court and settled their divorces (Sarangoo. R., 2015). Compared to the statistics of the 2007 the divorce rate increased by 5.7 percent related with the increase of the migration. Typically migrant workers are people who leave their family in their home countries. It is considered as one of the reasons for the divorce (Ministry of Population development and Social Welfare protection report, 2015).

Gender and family related issues started since the migration process started and they have been continuing and may increase. There is no proper policy cooperation policy on gender and family re-union in Mongolia. Except a single visit of a family member to migrant worker during the work contract no other alternatives solving the issue have not provided yet. Although international conventions advice inclusion of the current matter on the bilateral agreement, in reality the enforcement remains unsatisfactory.

According to the reports the record on death among the migrant workers reveals that infringement of the no monitoring on implementation of the contract made between two countries. It demonstrates that labor migration policy that meets international labor standard is getting a priority.

Figure 2: Sectors involved

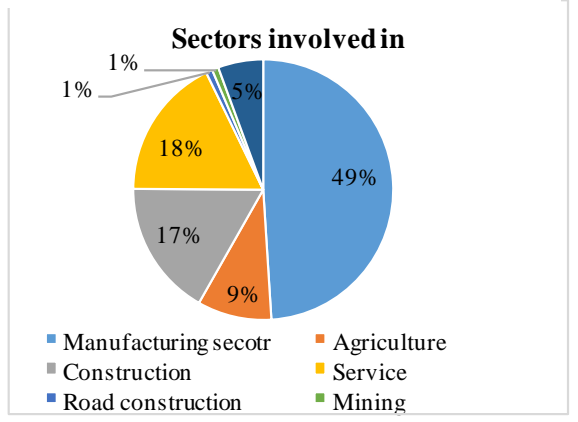

Figure 3: Working conditions

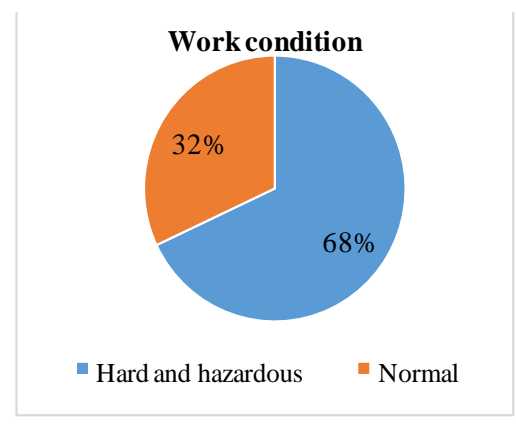

Forty seven percent of the survey participants had higher and special professional college education. Limited job opportunity and no 
discretion in selection of migrant worker for contractual work made these people to choose this employment option in the Republic of Korea.

Fifty nine percent of respondents replied that they sought the opportunity of improving their financial situation. It clearly demonstrates a low living standard of the population and a limited prospect of accessing social wealth of the country.

Respondents of the survey revealed that Mongolian migrant workers are mainly involved in labor that does not require any professional skills and the occupational health and safety issues ignored completely at the job and regularly work overtime. Labor standard addressing these challenges needs sharply, but to resolve above problems the database for recording violation of labor standard by sector, professional area and region is missing. Moreover, it is observed that the importance of labor market research system was essential.

Between 2007-2012 in Korea, 1006 migrant workers got victims of the production accidents and got injured and 13 of them died. Healthy applicants only qualify for the contractual work. The current and the previous surveys show that the migrant workers suffer from health concern at the end of the contract. No serious-minded actions taken by the Government of Mongolia to address the current problem up to present.

By the agreement made between the Government of Mongolia and the Republic of Korea 11449 citizens working in Korea enrolled in the pension insurance through the welfare protection program. The reasons for getting involved in the illegal labor serve visa expiration, low wage level of contractual work, breach of the contract terms, and health concerns.

Figure 4: Advantage of living abroad

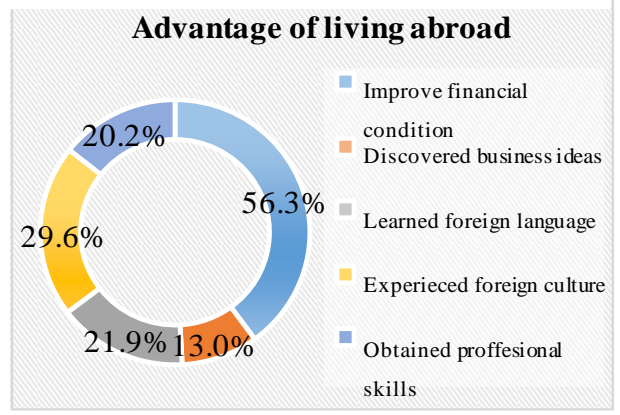

Figure 5: Negative sides of living abroad

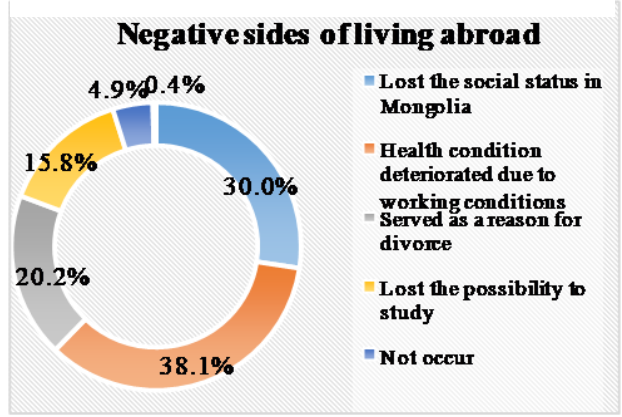


In regard to the advantage of living in Korea $56,3 \%$ of the respondents considered that they could improve the financial situation, $51,5 \%$ replied that they improved the foreign language proficiency and 20,2 $\%$ of the respondents noted that they obtained professional skills. As negative impacts $38,1 \%$ of the respondents considered that health was deteriorated by the work conditions, 30,0\% of them noted that they lost social status in home country, $20,2 \%$ of the respondents thought it lead to the divorce and $15.8 \%$ of them reflected that they lost an opportunity for furthering their education.

The rights of the Mongolian workers have been violated in the labor relations. The respondents considered that their rights were violated by working heavy load (53.0\%), overtime work (19,8\%), unpaid work (21,5\%) and not paying within the scheduled days and poor occupational health and safety $(19,4 \%)$. When they experience violation of their rights $60.7 \%$ of them would approach the Embassy of the home country, $8.1 \%$ of the respondents considered better to approach human rights organizations and $13.8 \%$ of them said they had no idea where to approach.

We concluded that there is not sufficient cooperation between Government, social stakeholders and institutions responsible for labor migration policy and the culture of cooperating with civil organizations and reflecting their recommendations on above issues have not nurtured yet.

Particularly, $68.8 \%$ of the respondents replied that they had lack of knowledge on the policy of the government of Mongolia on protecting the citizens' rights. It can be concluded that an accessible policy and measures are lacking among the citizens. Undoubtedly, there is a need to consider the necessity for professional body that will provide services such as counseling, legal assistance for the workers whose rights violated, and imposing fine and providing information for the worker and advocate their active participation.

Moreover, we observed that there is no particular policy for renaturalization of deported citizens including provision of job opportunities and resolving social issues. Only training procedures applied in the area that adopted from the international organization. Although Mongolia receives and deport immigrants, but the legal environment to regulate the rights of immigrants and their family members as the country has not joined the international convention. 


\section{Conclusion}

The study reviewed the current circumstance and challenging issues of migration of Mongolian citizens. The survey involved the citizens living and working in the Republic of Korea and Japan and produced the results based on the primary data.

We should note the limitations of the study considering the limitations of the research data and other sources which made us to consider the survey method which could assist us analyzing the legal framework of our country and it's' implications. The objective of the study is reviewing the conditions of the migration and conditions of the migrant workers working abroad. The results of the survey can be summarized as described below:

a. Occupational health and safety issues are may have been unsatisfactory in work places of Mongolian migrant workers;

b. Workers have lack of knowledge on migration laws and regulations;

c. Insufficient policy on cooperation in area of gender and family reunion possibility;

d. No significant measures are taken in this area except adopting the training procedures based on the experiences of an international organization

e. Missing policy on re-naturalization and socializing deported citizens;

f. Lack of cooperation between government and professional bodies responsible implementing policies; and

g. Not sufficient data or missing database on the migration.

Based on the above findings we propose the following recommendations:

1. For improving the governmental organizations of the countries:

a. Strengthen the legal environment and mechanisms resolving the health and social issues of foreign citizens in relation to the increase of violation of the rights of the citizens;

b. Investigate the possibility of resolving visa issues of Mongolian citizens working illegally in the Republic of Korea and Japan via diplomatic channels;

c. Accept the significance and benefits of migration labor in two countries in terms of employment, economic growth, development and poverty alleviation; 
d. Maintain efficient steps that involve planning, receiving and training in the migration practice of two countries; and establish an effective consular service;

e. Advocate application of international conventions, laws and standard in delivering and accepting migrant labor force.

2. Issues to be addressed by the government:

a. Maintain a policy on migrant labor that meet international labor standard;

b. Implement and develop the policy on migrant labor in alignment with the economic and social policies;

c. Carry out Legal reform: Law on delivering and accepting migrant labor force and related documents and regulations;

d. Maintain integrate information system that connected with data collection, analyzing and decision making scheme as it is essential for the evaluation of migrant labor policies;

e. Implement and improve the policy on re-naturalization and socializing returned citizens.

The study covered a limited frame only surveying the migrant workers. The further study will address not only social issues but also the opportunity of improving economic migration policy and social issues, legal framework of the social issues in a more comprehensive manner.

\section{Bibliography}

Batchuluun J., Bekhtur.B. (2004). “Labor Market”, book, p. 224

Sodnomdorj.N, (2000) "Modern labor economy", book, p. 15

Tungalag. D. (2012) "International migration of labor force in the end of XX and beginning of the XXI centuries", Research presentation, Ulaanbaatar.

Jandos. S. (2014) "Strengthening the labor migration of Mongolia", Research, Ulaanbaatar, p. 44

National Development Institute, (2012) "Research on naturalization, settlement and labor market", Research Presentation, Ulaanbaatar

Ministry of Labor, Labor research institute (2013) "Information bulletin on labor brokerage service", Report. Ulaanbaatar 
Ministry of Labor (2014) “Labor force study 2014”, Research Report, Ulaanbaatar

Ministry of Labor, Human rights education program. (2014). "Report on labor migration", Ulaanbaatar

IOM, (2011). Assisted Voluntary Return and Reintegration: Annual Report of Activities. Geneva

World Bank (2011) 'Migration and Remittance Factbook' 2nd Ed, p.16

World Bank (2015) RemittanceData_Outflows_April2013, accessed on. , p. 37

ZA, T. (2014). Islamic Studies dalam Pendekatan Multidisipliner (Suatu Kajian Gradual Menuju Paradigma Global). Jurnal Ilmiah Peuradeun, 2(2), 211-234. 